\title{
Notulae to the Italian native vascular flora: 2
}

Fabrizio Bartolucci', Gianniantonio Domina ${ }^{2}$, Michele Adorni ${ }^{3}$, Carlo Argenti ${ }^{4}$, Giovanni Astuti ${ }^{5}$, Sergio Bangoni ${ }^{6}$, Fabrizio Buldrini ${ }^{7}$, Mirella Benedetta Campochiaro ${ }^{8}$, Francesca Carruggio ${ }^{8}$, Lorenzo Cecchi 9 , Fabio Conti', Antonia Cristaudo ${ }^{10}$, Francesco Saverio D’Amico ${ }^{8}$, Giuseppe D’Auria ${ }^{11}$, Emilio Di Gristina ${ }^{12}$, Franz-Georg Dunkel ${ }^{13}$, Luigi Forte ${ }^{8}$, Carmen Gangale ${ }^{14}$, Luigi Ghillani ${ }^{15}$, Günter Gottschlich ${ }^{16}$, Francesca Mantino ${ }^{8}$, Mauro Mariotti ${ }^{17}$, Carmen Novaro $^{17}$, Nicola Olivieri ${ }^{18}$, Gino Palladino ${ }^{19}$, Maurizio Pascale ${ }^{20}$, Alessandra Pepe ${ }^{8}$, Enrico Vito Perrino ${ }^{21}$, Lorenzo Peruzzi ${ }^{5}$, Sergio Picollo ${ }^{22}$, Domenico Puntillo ${ }^{14}$, Francesco Roma-Marzio ${ }^{5}$, Alessandro Rosiello ${ }^{8}$, Giovanni Russo ${ }^{23}$, Claudio Santinii ${ }^{24}$, Federico Selvi ${ }^{25}$, Filippo Scafidi ${ }^{12}$, Anna Scoppola ${ }^{26}$, Adriano Stinca ${ }^{27}$, Milena Villa ${ }^{28}$, Chiara Nepi ${ }^{29}$

I Scuola di Bioscienze e Medicina Veterinaria, Università di Camerino - Centro Ricerche Floristiche dell'Appennino, Parco Nazionale del Gran Sasso e Monti della Laga, San Colombo, 67021 Barisciano (L'Aquila), Italy 2 Dipartimento di Scienze Agrarie e Forestali, Università degli Studi di Palermo, Via Archirafi 38, 90123 Palermo, Italy 3 Via degli Alpini 7, 43037 Lesignano de Bagni (Parma), Italy 4 Via Pietriboni 7, 32100 Belluno, Italy 5 Dipartimento di Biologia, Università di Pisa, Via Derna 1, 56126 Pisa, Italy 6 Via Sarcidano vic E snc, 08029 Siniscola (Nuoro), Italy 7 Dipartimento di Scienze Biologiche, Geologiche e Ambientali, Università di Bologna. Via Irnerio 42, 40126 Bologna, Italy 8 Museo Orto Botanico - Campus Universitario "E. Quagliariello", Università degli Studi di Bari, Via Orabona 4, 70125 Bari, Italy 9 Università degli Studi di Firenze, Museo di Storia Naturale, sezione botanica "Filippo Parlatore", Via G. La Pira 4, 50121 Florence, Italy 10 Dipartimento di Scienze Biologiche, Geologiche e Ambientali, Università degli Studi di Catania, Via A. Longo 19, 95124 Catania, Italy I I Servizio Fitosanitario, Regione Lazio, Via del Serafico 107, 00142 Roma, Italy I 2 Dipartimento STEBICEF, Sezione di Botanica ed Ecologia vegetale, Università degli Studi di Palermo, Via Archirafi 38, 90123 Palermo, Italy 13 Am Saupurzel 1, D-97753 Karlstadt, Germany 14 Museo di Storia Naturale della Calabria ed Orto Botanico, Università della Calabria, 87036 Arcavacata di Rende (Cosenza), Italy 15 Via Carlo Casalegno 6, 43123 Parma, Italy 16 Hermann-Kurz-Strasse 35, D-72074 Tübingen, Germany 17 Università di Genova. DISTAV. Dipartimento di Scienze della Terra, dell'Ambiente e della Vita, Corso Europa 26. 16132 Genova, Italy I8 Via Maestri del Lavoro 40, 64100 Teramo, Italy 19 Via Soldato Ercolino 14, 71013 San Giovanni Rotondo (Foggia), Italy 20 Via della Repubblica 14, 12018 Roccavione (Cuneo), Italy 2 I CIHEAM, Agronomic Mediterranean Institute of Bari, Via Ceglie 9, 70010 Valenzano (Bari), Italy 22 Via Alcide De Gasperi 8, 43044 Collecchio (Parma), Italy 23 Via Ercolino, n. 11, 71013 San Giovanni Rotondo (Foggia), Italy 24 Gruppo Flora del Modenese, Via Sant'Orsola 7, 41121 Modena, Italy 25 Università degli Studi di Firenze, Dipartimento di Scienze delle Produzioni Agroalimentari e dell'Ambiente (DISPAA), Laboratori di Botanica, Piazzale delle Cascine 28, 50144 Firenze, Italy 26 DAFNE, Dipartimento di Scienze Agrarie e Forestali, Università della Tuscia, Via San Camillo de Lellis snc 01100 Viterbo, Italy 27 Dipartimento di Agraria, Università di Napoli Federico II, Via Università 100, 80055 Portici (Napoli), Italy 28 Via Lauro 4, 23888 La Valletta Brianza (Lecco), Italy 29 Sezione di Botanica Filippo Parlatore, Museo di Storia Naturale, Università di Firenze, Via G. La Pira 4, 50121 Firenze, Italy

Copyright Fabrizio Bartolucci et al. This is an open access article distributed under the terms of the Creative Commons Attribution License (CC BY 4.0), which permits unrestricted use, distribution, and reproduction in any medium, provided the original author and source are credited. 
Corresponding author: Fabrizio Bartolucci (fabrizio.bartolucci@gmail.com)

Academic editor: S. Biondi | Received 7 November 2016 | Accepted 15 November 2016 | Published 29 November 2016

Citation: Bartolucci F, Domina G, Adorni M, Argenti C, Astuti G, Bangoni S, Buldrini F, Campochiaro MB, Carruggio F, Cecchi L, Conti F, Cristaudo A, D’Amico FS, D’Auria G, Di Gristina E, Dunkel F-G, Forte L, Gangale C, Ghillani L, Gottschlich G, Mantino F, Mariotti M, Novaro C, Olivieri N, Palladino G, Pascale M, Pepe A, Perrino EV, Peruzzi L, Picollo S, Puntillo D, Roma-Marzio F, Rosiello A, Russo G, Santini C, Selvi F, Scafidi F, Scoppola A, Stinca A, Villa M, Nepi C (2016) Notulae to the Italian native vascular flora: 2. Italian Botanist 2: 73-92. doi: 10.3897/ italianbotanist. 2.11060

\begin{abstract}
In this contribution new data concerning the Italian distribution of native vascular flora are presented. It includes new records, exclusions, and confirmations to the Italian administrative regions for taxa in the genera Arctostaphylos, Artemisia, Buglossoides, Convolvulus, Crocus, Damasonium, Epipogium, Ficaria, Filago, Genista, Heptaptera, Heracleum, Heteropogon, Hieracium, Myosotis, Ononis, Papaver, Pilosella, Polygonum, Pulmonaria, Scorzonera, Silene, Trifolium, Vicia and Viola.
\end{abstract}

\title{
Keywords
}

Floristic data, Italy

\section{How to contribute}

The text for the new records should be submitted electronically to Chiara Nepi (chiara. nepi@unifi.it). The corresponding specimen has to be sent to FI Herbarium: Sezione di Botanica Filippo Parlatore del Museo di Storia Naturale, Via G. La Pira 4, 50121 Firenze (Italy). Those texts concerning nomenclatural novelties (typifications only for accepted names), exclusions, and confirmations should be submitted electronically to: Fabrizio Bartolucci (fabrizio.bartolucci@gmail.com). Each text should be within 2,000 characters (spaces included).

\section{Floristic records}

\section{Arctostaphylos uva-ursi (L.) Spreng. (Ericaceae)}

+ CAL: San Donato di Ninea (Cosenza), Cozzo del Pellegrino (WGS84: $39.739022^{\circ} \mathrm{N}$, $16.004854^{\circ} \mathrm{E}$ ), margine di faggeta di quota, su pietraia calcarea, $1880 \mathrm{~m}, 19$ September 2015, Leg. D. Puntillo, Det. D. Puntillo \& C. Gangale (FI, CLU, Herb. Gangale \& Uzunov). - Species new for the flora of Calabria.

This species is a well-known circumboreal Artic-Alpine element, recorded in Italy on the Alps, in the northern and central Apennines and up to Campania (Conti et al. 
2005). A small population, covering about $12 \mathrm{~m}^{2}$, was observed on the top of Cozzo del Pellegrino, one of the highest peaks of Orsomarso mountains, in the SW sector of Mt. Pollino. Its finding in Calabria is very significant because it extends southward the distribution of this taxon.

D. Puntillo, C. Gangale

\section{Artemisia arborescens (Vaill.) L. (Asteraceae)}

+ (CAS) ABR: San Vito Chietino (Chieti), località Marina, bordi di una canaletta in cemento per il deflusso delle acque meteoriche situata sul margine stradale (WGS84: $42.307681^{\circ} \mathrm{N} ; 14.446533^{\circ} \mathrm{E}$ ), ca. $25 \mathrm{~m}, 10$ July 2016, N. Olivieri (FI). - Casual alien species new for the flora of Abruzzo.

An individual of this species grows in a crevice of the edge of a concrete channel in a shaded area and next to the Adriatic Sea. The site of discovery is located in an urban area and the individual has grown from seed produced by a plant cultivated for ornamental purposes in a private garden.

N. Olivieri

Buglossoides incrassata (Guss.) I.M.Johnst. subsp. permixta (Jord.) L.Cecchi \& Selvi (Boraginaceae)

+ IT: valle della Dora Riparia [Torino] inter Salbertrand et Oulx (WGS84: $45.054531^{\circ} \mathrm{N} ; 6.858531^{\circ} \mathrm{E}$ ), 22 Jun 1879, F Ungern-Sternberg (TO); Alpi Cozie [Torino], nei coltivati presso Chiomonte (WGS84: $45.115814^{\circ} \mathrm{N} ; 6.976436^{\circ} \mathrm{E}$ ), Oulx e Boulard, 18 May 1896, E. Ferrari \& F. Vallino (FI); Saluzzo [Cuneo], Mongrosso, La Manta (WGS84: $44.618680^{\circ} \mathrm{N} ; 7.483210^{\circ} \mathrm{E}$ ), 8 May 1909, A. Zola, Herb. Gavioli No.6281 (FI); Argentera [Cuneo] (WGS84: $44.395602^{\circ} \mathrm{N}$; $6.938284^{\circ} \mathrm{E}$ ), pendici d'Alpe [illegible], 28 May [illegible], G.B. Biadego (VER); valle di Susa [Torino], Signols (WGS84: $45.044566^{\circ} \mathrm{N} ; 6.801774^{\circ} \mathrm{E}$ ), prati falciati e prati abbandonati nei pressi dell'abitato, 1100 m, 4 Jun 1980, F. Montacchini, Lomagno \& G. Forneris (TO). - Subspecies new for the flora of Italy (Piemonte).

Based on the recent findings by Cecchi et al. (2014), Buglossoides incrassata (Guss.) I.M. Johnst. occurs in Italy with two subspecies: $B$. incrassata subsp. incrassata and $B$. incrassata subsp. splitgerberi (Guss.) E.Zippel \& Selvi. The former is found in Sicily and in part of the southern regions, while the latter is distributed in Sicily and part of the peninsular and northern regions. However, its exact distribution requires further investigation and is still to be defined. Based on both morphological and molecular data (Cecchi et al. 2014), Lithospermum permixtum Jord. also belongs to the B. incrassata complex, rather than in the B. arvensis group as proposed by Fernandes (1972) and 
accepted by most authors (e.g. Aeschimann et al. 2004, Conti et al. 2005). Accordingly, it was recently transferred to this species as B. incrassata subsp. permixta. This is a W Mediterranean taxon occurring from S Spain to the Maritime Alps, especially the French parts (Tison and De Foucault 2014). The historical herbarium records found in FI (originally identified as Lithospermum arvense L. var. coerulescens DC.), TO (one of which originally identified as $L$. arvense L. var. coerulescens DC., the other already referred by F. Ungern-Sternberg to L. permixtum Jord.) and VER (originally identified as $L$. arvense L.) show the presence of this taxon also in Piemonte, where it probably reaches its eastern limit.

L. Cecchi, F. Selvi

\section{Convolvulus cneorum L. (Convolvulaceae)}

+ SAR: Baunei (Ogliastra), Golfo di Orosei, Bacu Padente (WGS84: 40.13944 N; $9.65880^{\circ} \mathrm{E}$ ), cenge su pareti calcaree, $145 \mathrm{~m}, 2$ June 2016, S. Bangoni (FI). - Species new for the flora of Sardegna.

Convolvulus cneorum is recorded for Tunisia, Sicilia, Tyrrhenian coast of the Italian peninsula from Calabria to Toscana (the occurrence in Lazio is doubtful), and Ionian coast of the Balkan peninsula from Croatia to Albania (Greuter et al. 1986, Conti et al. 2005, Nikolić 2016). The population reported here is very far from any residential area, supporting the native status of the species in Sardegna.

S. Bangoni

Crocus neapolitanus (Ker Gawl.) Loisel. (Iridaceae)

- PIE. - Species to be excluded from the flora of Piemonte.

- LOM. - Species to be excluded from the flora of Lombardia.

- MAR. - Species to be excluded from the flora of Marche.

\section{Crocus neglectus Peruzzi \& Carta (Iridaceae)}

+ PIE: Valle Tanaro, tra Garesso e Trappa (Cuneo) (WGS84: $44.189^{\circ} \mathrm{N} ; 8.009^{\circ} \mathrm{E}$ ), prato, 620 m, 12 March 2014, Leg. M. Pascale, Det. L. Peruzzi (PI); Valle Tanaro, poco a valle dell'abitato di Nucetto (Cuneo) (WGS84: $44.3446^{\circ} \mathrm{N} ; 8.0590^{\circ} \mathrm{E}$ ), prato falciato, 445 m, 12 March 2014, Leg. M. Pascale, Det. L. Peruzzi (FI). - Species new for the flora of Piemonte.

+ LOM: Ai piedi di M. Palanzone: luoghi selvatici, 14 March 1889, Mari (FI, as Crocus vernus All. var. medius Parl.); Merate (Lecco), al termine di via Regondino, confinante 
con via Paravino di Cernusco Lombardone (WGS84: $45.702637^{\circ} \mathrm{N}$; $9.394753^{\circ} \mathrm{E}$ ), boscaglia, 270 m, 28 February 2007, Leg. M. Villa, Det. L. Peruzzi (FI). - Species new for the flora of Lombardia.

0 UMB: Pascoli prope M.te Pennino, s.d., A. Batelli (FI, as Crocus vernus L.); M.te Pennino, May 1886, A. Batelli (FI, as C. vernus). - Species new for the flora of Umbria, not recently confirmed.

+ MAR: Fonte Verna, M. Catria, 21 May 1924, Aiuti (FI, as Crocus vernus Hill); Monti Sibillini, Rifugio Sibilla (WGS84: $42.90823^{\circ} \mathrm{N} ; 13.29145^{\circ} \mathrm{E}$ ), 1536 m, 25 April 2014, L. Peruzzi, B. Pierini (PI). - Species new for the flora of Marche.

0 ABR: Monte dei Fiori pr. Ascoli, May 1874, P. Porta, G. Rigo (FI, as Crocus). - Species new for the flora of Abruzzo, not recently confirmed.

According to Harpke et al. (2015), seven species of Crocus ser. Verni occur in Italy: the autumn flowering C. longiflorus Raf., occurring in S Italy and Sicily; the short-styled, spring flowering C. siculus Tineo and C. vernus (L.) Hill, endemic to Sicily the former, very common above $1,500 \mathrm{~m}$ in N Italy, the second; the longstyled, spring flowering C. etruscus Parl., C. ilvensis Peruzzi \& Carta, C. neapolitanus (Ker Gawl.) Loisel. (= C. vernus auct. pro parte), C. neglectus Peruzzi \& Carta (= C. vernus auct. pro parte). While the first two taxa, both narrow endemics to Toscana, are not particularly problematic (Carta et al. 2010, Peruzzi and Carta 2011, Harpke et al. 2015), whereas the remaining species (C. neapolitanus and C. neglectus) are more difficult to identify. Crocus neapolitanus has been recorded generically for the "Italian peninsula", but it is absent from Emilia-Romagna, Liguria, and Toscana, where C. neglectus occurs (Harpke et al. 2015). Given that records of long-styled plants are known also for other regions in northern (see e.g. Aeschimann et al. 2004) and central Italy, we carried out herbarium and field studies in order to clarify the distribution of these taxa. In a previous work, Peruzzi et al. (2013) already showed that in Valle D'Aosta only C. vernus (L.) Hill s.str. occurs. According to our results, it was possible to highlight that the plants so far referred to as "C. neapolitanus" or "C. vernus auct." from Friuli Venezia Giulia actually belong to an eighth species, not previously recorded for Italy: C. heuffelianus Herb. (Peruzzi 2016a). The plants referred to as "C. vernus auct." or "C. neapolitanus" in Lombardia, Piemonte, Marche, most of Umbria and a single locality in the very Northern Abruzzo actually pertain to $C$. neglectus. It should be noted that, based on the specimen cited above, the occurrence in Abruzzo remains questionable. Indeed, Montagna dei Fiori is a mountain range falling across the administrative borders between Marche and Abruzzo. However, given that most of the mountain meadows (typical habitat for C. neglectus) pertain to the territories of Abruzzo, we believe its historical presence in this administrative region to be plausible. Incidentally, the rejection of the name C. purpureus Weston, which should have nomenclatural priority for the latter species, was recently proposed (Peruzzi 2016b). While C. neapolitanus certainly also occurs in Abruzzo, we can safely exclude this species from Piemonte, Lombardia and Marche. Gaps in distribution (and/or in knowledge) of these plants are apparent between Lombardia and Veneto, and in parts of central Italy between northern Lazio/ 
Abruzzo and southern Toscana/Umbria/Marche. Further field investigations should be carried out in these areas, to check if these taxa are completely allopatric, as the data available today seem to suggest.

L. Peruzzi, M. Villa \& M. Pascale

\section{Crocus variegatus Hoppe \& Hornsch. (Iridaceae)}

+ EMR: Sala Baganza (Parma), Boschi di Carrega (WGS84: $44.721914^{\circ} \mathrm{N}$; 10.211219 ${ }^{\circ}$ E), 180-200 m, February 2016, Leg. S. Picollo, L. Ghillani, M. Adorni, Det. L. Peruzzi (FI, PI). - Species confirmed for the flora of Emilia-Romagna.

According to Harpke et al. (2014), Crocus variegatus Hoppe \& Hornsch. is a bulbous geophyte occurring from Italy to northwestern Balkans. The known Italian populations, recorded from Friuli Venezia Giulia, Lazio and Abruzzo (Conti et al. 2005, Bartolucci 2007), were previously wrongly referred to C. reticulatus Steven ex Adams, a species endemic to the Caucasus (Harpke et al. 2014). A historical record of " $C$. variegatus" does exist for Emilia-Romagna (Parlatore 1858: "Barbieri me ne ha favorita una pianta dei monti di Parma: dubito però di sbaglio di luogo" [Barbieri provided me with a plant from the moutains around Parma: however I suspect that the locality is erroneous]); the same record was later quoted by Bolzon (1920). In the light of our finding, the presence of this species in the Parma province (and in Emilia-Romagna) is indeed fully confirmed. Crocus variegatus has been found in three distinct localities within the Parco Boschi di Carrega, but its occurrence also in other parts of the protected area is likely.

S. Picollo, L. Peruzzi, L. Ghillani \& M. Adorni

\section{Damasonium polyspermum Coss. (Alismataceae)}

+ PUG: Mottola (Taranto), Masseria Semeraro (UTM ED50: 33T 4498003N; 674582E), vegetazione acquatica, 29 April 2010, Leg. et Det. E.V. Perrino, Rev. L. Forte \& F. Carruggio (BI-35781, as Damasonium alisma subsp. alisma); Mottola (Taranto), Masseria Semeraro, lungo la S.P. 28, (WGS84: $40.612708^{\circ} \mathrm{N} ; 17.062869^{\circ} \mathrm{E}$ ), vaschetta di erosione su substrato calcareo, $136 \mathrm{~m}$ s.l.m., 08 May 2014, Leg. F. Carruggio, F. Mantino \& L. Forte, Det. F. Carruggio, F. Mantino \& L. Forte (FI); Mottola (Taranto), Masseria Semeraro, lungo la S.P. 28, (WGS84: $40.612708^{\circ} \mathrm{N} ; 17.062869^{\circ} \mathrm{E}$ ), vaschetta di erosione su substrato calcareo, $136 \mathrm{~m}$ s.l.m., 8 May 2014, Leg. F. Carruggio, F. Mantino \& L. Forte, Det. F. Carruggio, F. Mantino \& L. Forte (BI-36676). - Species new for the flora of Puglia.

This taxon is one of at least two species currently accepted for Damasonium Mill. in Europe and in the Mediterranean area, together with D. alisma Mill. (Pignatti 1982, 
Vuille 1987, Rich and Nicholls-Vuille 2001, Conti et al. 2005, Talavera and Talavera 2010). Conversely, not all authors recognize D. bourgaei Coss. as a distinct species, including it in D. alisma (Pignatti 1982, Conti et al. 2005). Damasonium polyspermum has a western-Mediterranean distribution (Rich and Nicholls-Vuille 2001), but it is present also in the Near East (Danin 2000). In Italy, this taxon was until now reported only in Sicilia (Conti et al. 2005). In Puglia, only D. alisma subsp. alisma has been recorded to date (Pignatti 1982, D'Amico and Signorile 2001, D'Amico et al. 2003, Conti et al. 2005, Giannico 2011, Alfonso et al. 2014). However, according to Alfonso et al. (2014) the presence of the taxon in the area of Alta Murgia, at the San Giuseppe pond, has to be confirmed, while the record near Masseria Semeraro reported by Giannico (2011) is probably to be considered erroneous, due to confusion with $D$. polyspermum. In fact, a herbarium specimen revision (BI-35781, Masseria Semeraro, Mottola, 29 April 2010, Perrino as D. alisma subsp. alisma) and new field surveys allowed to verify the presence of $D$. polyspermum in this site. The site is a small cupular pool, a karstic form in limestone. Less than 50 individuals were observed. Serious threats affect the site, especially owing to accidental and arson fires.

F. Carruggio, F. Mantino \& L. Forte

\section{Epipogium aphyllum Sw. (Orchidaceae)}

+ PUG: Monte Sant'Angelo (Foggia), Monte Spigno (WGS84: $41.7796^{\circ} \mathrm{N}$; $15.8819^{\circ} \mathrm{E}$ ), bordi di un sentiero in faggeta, suolo ricco in humus e calcare, $831 \mathrm{~m}, 30$ June 2016, L. Palladino (FI). - Species new for the flora of Puglia.

Epipogium aphyllum is a species with Eurosiberian distribution (Pignatti 1982), occurring in Italy in many regions, but not recorded in Valle d'Aosta, Umbria, Sardegna and, until now, Puglia (Perazza 2016). In the Puglia site, we found only a single plant. After undertaking a rich photographic documentation, a specimen with a single flower and part of the stem was prepared and stored in FI.

L. Palladino, G. Russo

\section{Ficaria verna Huds subsp. calthifolia (Rchb.) Nyman (Ranunculaceae)}

$\equiv$ Ranunculus ficaria L. subsp. calthifolius (Rchb.) Arcang.

+ PUG: Monte Cornacchia (Faeto, prov. Foggia) (WGS84: $41.363233^{\circ} \mathrm{N} ; 15.157632^{\circ} \mathrm{E}$ ), margine rimboschimento a conifere, $1138 \mathrm{~m}$, WSW, 24 April 2015, A. Stinca, G. D'Auria, E.V. Perrino (FI, PORUN). - Species confirmed for the flora of Puglia.

Ficaria verna subsp. calthifolia is distributed in eastern-central and southeastern Europe, and Libya (Sell 1994, Veldkamp 2015, Hörandl and Raab-Straube 2015). 
It was previously reported in Puglia by Fenaroli (1970, sub Ranunculus ficaria subsp. calthaefolius) from "Monte Nero, in vetta" [Mt. Nero, on the top], but not recently confirmed (e.g. Conti et al. 2005, 2007, Wagensommer et al. 2014).

A. Stinca, G. D’Auria \& E.V. Perrino

\section{Filago pygmaea L. (Compositae)}

+ LIG: Cervo (Imperia), pendici SW del Colle di Cervo, a lato della "Strada al Ciapà", tra Cervo e Bande di Là-Rollo (WGS84: 4355'43"N; 87'19"E), 155 m, 2 August 2016, C. Novaro, det. M. Mariotti (FI). - Species confirmed for the flora of Liguria.

De Notaris (1844, as Evax pygmaea (L.) Brot.) recorded this species for the first time in Liguria at "Bordighiera" on the basis of a specimen collected by Panizzi. Ricca (1870) cited $E$. pygmaea as abundant in dry places with compact soil of the coastal zone, under $400 \mathrm{~m}$ a.s.l., of Diano Marina and Cervo Valleys (western Liguria). Conti et al. (2005) cited the species as no longer recorded in Liguria and not present in the other regions of northern Italy. The population reported here is estimated at just over 100 individuals patchily scattered over an area of about $200 \mathrm{~m}^{2}$. The habitat belongs to the Filagini-Vulpietum Oberd. association and falls within the Priority Habitat type 6220 according to Annex I of Directive 92/43/EEC. Filago pygmaea seems to be expanding, but there are threats such as fires, fragmentation linked to the presence of a road, and abandonment of waste.

C. Novaro, M. Mariotti

\section{Genista etnensis (Raf.) DC. (Fabaceae)}

+ (CAS) ABR: L'Aquila (L'Aquila), loc. Monteluco di Roio, incolto su pendio presso il bordo stradale (WGS84: $42.339202^{\circ} \mathrm{N} ; 13.374081^{\circ} \mathrm{E}$ ) ca. $980 \mathrm{~m}, 30$ June 2016, $N$. Olivieri (FI). - Casual alien species new for the flora of Abruzzo.

Some individuals of this species, of different ages, have colonized the barren slopes facing SW at the edge of the road leading up to the summit of Monte Luco di Roio. The plants have originated from some individuals introduced in the past in a reforestation area with conifers.

N. Olivieri

Heptaptera angustifolia (Bertol.) Tutin (Apiaceae)

+ PUG: Spinazzola (Bari), Vallone Ciotola (WGS84: $40.970169^{\circ} \mathrm{N} ; 16.068883^{\circ} \mathrm{E}$ ), 370 m s.l.m., cerreta 15 July 2014, F. Carruggio, A. Rosiello \& L. Forte (BI-36678); 
Spinazzola (Bari), Vallone Ciotola (WGS84: $\left.40.971622^{\circ} \mathrm{N} ; 16.070078^{\circ} \mathrm{E}\right), 360 \mathrm{~m}$ s.l.m., cerreta, 15 July 2014, F. Carruggio, A. Rosiello \& L. Forte (BI-36679). - Species confirmed for the flora of Puglia.

Heptaptera, a small genus of the Apiaceae, has a distribution centered mostly in the Balkan region and the Middle East (Roskov et al. 2016). This species is endemic to southern Italy (Peruzzi et al. 2014, 2015), and it is also the unique member of this genus in the Italian peninsula (Tutin 1968). It was certainly known until today only in Basilicata (Conti et al. 2005) and Calabria (Bernardo 2014). Differently its presence in Puglia was uncertain (Conti et al. 2005, Wagensommer et al. 2013), based on a single ancient finding by Gasparrini ("ex maritimis Apuliae prope Gravinam a Gasparrinio", Bertoloni 1838), repeatedly cited by several authors (Caruel 1889, Fiori 1925, Pignatti 1982). This new locality lies in a sub-mesophilous Turkey oak wood, alongside the slope of one of the erosive cracks, locally known as "valloni", which are present in the Spinazzola area. Only about 30 individuals were observed.

F. Carruggio, A. Rosiello \& L. Forte

\section{Heracleum sphondylium L. subsp. sibiricum (L.) Simonk. (Apiaceae)}

+ CAL: San Giovanni in Fiore (Cosenza), presso la diga del Lago Arvo, Loc. Nocelle (WGS84: $39.247042^{\circ} \mathrm{N}, 16.544429^{\circ} \mathrm{E}$ ), margine pineta, $1308 \mathrm{~m}, 19$ July 2015, Leg. D. Puntillo, det. D. Puntillo \& C. Gangale (FI, CLU, Herb. Gangale \& Uzunov). Subspecies confirmed for the flora of Calabria.

In Calabria, this species is rare and known only in Mt. Pollino, where H. sphondylium subsp. elegans (Crantz) Schubl. \& G.Martens is recorded. The population found in Mt. Sila, new for this territory, consists of about 10-12 individuals, along a road at the edge of a pine forest. Morphological characters of leaves and fruits are those of $H$. sphondylium subsp. sibiricum (Klimko et al. 2013), which Conti et al. (2005) considered as recorded in the past by mistake in Calabria. The old record of H. sphondylium var. cordatum (Gavioli 1932) for Mt. Pollino has to be referred to H. sphondylium subsp. elegans.

D. Puntillo, C. Gangale

\section{Heteropogon contortus (L.) P. Beauv. ex Roem. \& Schult. (Poaceae)}

+ PUG: Manfredonia (Foggia), sulla strada tra Manfredonia e Ruggiano, (UTM ED50: 33T 4613017N; 573381E), 310 m s.l.m., prateria rocciosa, 19 July 1995, Leg. F.S. D’Amico \& L. Forte, Det. F.S. D’Amico \& L. Forte (BI- 36680); San Giovanni Rotondo (Foggia), a monte di C. Lanzetta, (WGS84: $41.659578^{\circ} \mathrm{N} ; 15.807217^{\circ} \mathrm{E}$ ), 290 m s.l.m., prateria a Stipa oligotricha, 17 March 2007, Leg. F. Mantino \& L. Forte, Det. 
F. Mantino \& L. Forte (BI-36681); Laterza (Taranto), a est di Masseria Gallo, lungo la S.P. 8, (WGS84: $\left.40.576425^{\circ} \mathrm{N} ; 16.817828^{\circ} \mathrm{E}\right), 190 \mathrm{~m}$ s.l.m., pascolo roccioso, 14 September 2007, Leg. F. Carruggio \& L. Forte, Det. F. Carruggio \& L. Forte (BI-36677); Laterza (Taranto), Canale S. Pellegrino, (WGS84: $\left.40.577404^{\circ} \mathrm{N} ; 16.785956^{\circ} \mathrm{E}\right), 214$ $\mathrm{m}$ s.l.m., prateria rocciosa, 3 December 2007, Leg. F. Carruggio, Det. F. Carruggio \& A. Cristaudo (FI). - Species new for the flora of Puglia.

This termophilous species occurs in large tropical and subtropical areas of the world (Pignatti 1982, USDA 2011). In Europe, it is present mostly in the central-western Mediterranean region (Clayton 1980), while it is very rare eastwards (Euro+Med 2006 onwards). In Italy, it is quite uncommon although reported, with some gaps, for several regions in the north, in the centre and in the south of the country (Conti et al. 2005). There is only an informal note about the presence of this taxon in Puglia (Acta Plantarum 2008). The occurring sites are characterized by thermophilous xeric grassland communities located in the Gargano and in the area of Arco Jonico.

F. Mantino, F. Carruggio, F.S. D’Amico, A. Cristaudo \& L. Forte

\section{Hieracium falcatum Arv.-Touv. subsp. falcatum (Asteraceae)}

+ VDA: Aosta (Aosta), 1,1 km NW Chardonney, Straße Richtung Dondenaz (WGS84: 453'32"N; 07³5'39"E), Felsrasen, Schotterflur über Kalk, 1860 m, 10 August 2014, F. G. Dunkel (FI, Herb. Dunkel, Herb. Gottschlich). - Species confirmed for the flora of Valle d'Aosta.

Hieracium falcatum was recorded in Italy by Vignolo-Lutati (1953) based on specimens collected in Valle d'Aosta. This record was not reported by Conti et al. (2005) and Bovio (2014). Hieracium falcatum subsp. falcatum is a rare endemic to the western Alps, recorded for France in Savoie (Col du Galibier), Haute-Savoie (Chapelle d'Abondance, Vallorcine, Passy, Col de Vernaz) and in the Département des Hautes-Alpes (Col du Lautaret, Montgenèvre). Two other subspecies, H. falcatum subsp. glaucoides (Beck) Zahn and $H$. falcatum subsp. falcatiforme (Degen \& Zahn) Zahn, occur in Austria, southern Austria (Schneeberg), and in Croatia (Istria, Velebit) (Zahn 1922-1938).

G. Gottschlich, F.G. Dunkel

\section{Myosotis speluncicola (Boiss.) Rouy (Boraginaceae)}

+ MAR: Montefortino (Fermo), Parco Nazionale dei Monti Sibillini, Gole dell'Infernaccio (WGS84: $42.914257^{\circ} \mathrm{N} ; 13.255262^{\circ} \mathrm{E}$ ), shady rock crevices along the pathway going across the gorges of Fiume Tenna, 1102 m, 24 May 2016, L. Peruzzi (FI, PI). - Species confirmed for the flora of Marche. 
Myosotis speluncicola is a rare annual species with scattered distribution in Europe, occurring in SE France, Balkans, S Anatolia, and possibly extending to N \& W Iran (Strid and Tan 1999, Barina and Pifkó 2008). It also certainly occurs in Italy in Abruzzo (Conti and Bartolucci 2016, Conti et al. 2016), and in Trentino-Alto Adige (Bertolli and Prosser 2011), whereas it was historically recorded in the Marche (Conti et. al 2005). The presence in this region is based on some ancient specimens preserved in FI and collected in the so-called "Grotta di Foce Scura" on the Sibillini massif (Béguinot 1904 as M. marcillyana Burnat ex Bég., Fiori 1907 as M. arvensis var. marcillyana (Burnat ex Bég.) Fiori, Grau 1968, Pignatti 1982). According to Ballelli et al. (2010) this species should be excluded from the massif, but its historical presence is confirmed by Conti et al. (2016).

L. Peruzzi, F. Roma-Marzio

\section{Ononis alopecuroides L. subsp exalopecuroides (G. López) Greuter \& Burdet (Fabaceae)}

+ PUG: Bari (Bari), nei pressi dell'area commerciale (WGS84: $16.906557^{\circ} \mathrm{N}$; $41.078590^{\circ} \mathrm{E}$ ), prateria annuale a Stipa capensis Thunb. su substrato di natura calcarea, 43 m s.l.m., 6 May 2016, Leg. A. Pepe \& M.B. Campochiaro, Det. A. Pepe \& F. Carruggio (FI); Bari (Bari), a ridosso della S.S. 100 (WGS84: $16.904580^{\circ} \mathrm{N} ; 41.074979^{\circ} \mathrm{E}$ ), prateria annuale a Stipa capensis Thunb. su substrato di natura calcarea, $46 \mathrm{~m}$ s.l.m., 26 May 2016, M.B. Campochiaro \& A. Pepe, det. A. Pepe \& F. Carruggio (BI-36674, BI-36675). - Species and subspecies new for the flora of Puglia.

This stenomediterranean entity is present in north-western Africa (Algeria, Morocco, Tunisia), Corsica, Malta and in the eastern Mediterranean countries (Lebanon, Syria, Israel and Jordan); it is doubtfully native in the ex-Yugoslav area, doubtfully present in Greece and adventitious in France (Greuter et al. 1989). In Italy, it was known until today in Sicilia, Calabria, Basilicata (Conti et al. 2005), Abruzzo (Conti et al. 2016), Campania (Nazzaro et al. 2007), and Sardegna (De Martis et al. 2009), while it was no longer recorded in Liguria, despite previously being reported by Pignatti (1982). Therefore, the present records extend eastward the Italian distribution area. Both occurring sites, only about $500 \mathrm{~m}$ from each other, are close to the urban area of Bari, in no longer cultivated fields, the second one being closer to olive groves. The sites are characterized by sub-nitrophilous annual communities. Isolated individuals of this taxon were recorded. Because of its therophytic life-form and the probable soil seed bank formation, being a leguminous plant, it would be interesting to verify the actual rarity of the taxon in relation to possible fluctuations in the number of individuals over the years.

A. Pepe, F. Carruggio, M.B. Campochiaro \& L. Forte 


\section{Papaver setigerum DC. (Papaveraceae)}

+ ABR: Francavilla (Chieti), loc. Postilli, margini della massicciata ferroviaria ed incolti al bordo della Strada Statale 16 Adriatica, (WGS84: $42.402141^{\circ} \mathrm{N} ; 1^{2} .321103^{\circ} \mathrm{E}$ ), bordo stradale, ca. 3 m, 14 May 2016, N. Olivieri (FI). - Species new for the flora of Abruzzo.

+ MOL: Campomarino (Campobasso) loc. Nuova Cliternia, vegetazione lungo il bordo della Strada Statale 16 Adriatica, (WGS84: $41.935792^{\circ} \mathrm{N} ; 15.091713^{\circ} \mathrm{E}$ ), bordo stradale, ca. 5 m, 29 March 2016, N. Olivieri (FI). - New species for the flora of Molise.

In Abruzzo. this species appears with some individuals together with Papaver rhoeas L. within ruderal thermophilic vegetation at the road edge and along the nearby railway embankment, on unstable sandy and gravelly soil. In Molise, some individuals of $P$. setigerum grow within the terophytic herbaceous vegetation settled on the edge of a road, on sandy substrate, in an area close to the Adriatic Sea. Papaver setigerum is a western Mediterranean species that, in Italy, was known for Sicilia, Sardegna, Calabria, Basilicata, Campania, Lazio, Toscana, Liguria (Conti et al. 2005) and Puglia (Biscotti 2002, Licht and Wagensommer 2008).

N. Olivieri

\section{Polygonum romanum Jacq. (Polygonaceae)}

+ SIC: Misilmeri (Palermo), locality Contrada Rigano (WGS84: 3801'23.11"N; $\left.13^{\circ} 26^{\prime} 49.54^{\prime} \mathrm{E}\right), 127 \mathrm{~m}$, road edge near waste land, 16 October 2015, F. Scafidi (PAL102713, FI). - Species new for the flora of Sicily.

This is a Mediterranean species typical of pastures, uncultivated lands and ruderal environments, not listed for Sicily by Conti et al. (2005) and Raimondo et al. (2010). The identification was made on the basis of the description by Raffaelli (1982). To date, the locality reported here represents the southern limit of the Italian range of this species.

F. Scafidi, E. Di Gristina \& G. Domina

\section{Pilosella glaciella (Nägeli \& Peter) Soják (Asteraceae)}

+ VEN: Malga Zingari Alti (Falcade, Belluno) (WGS84: 4621'07"N; 1148'26"E), pascolo su silice, 2100 m, 16 July 2015, C. Argenti (FI, Herb. Argenti). - Species new for the flora of Veneto.

Pilosella glaciella is a typical Alpine species, which always grows together with P. glacialis (Reyn. ex Lachen.) F.W.Schultz \& Sch.Bip. This leads to hypothesize that 
P. glaciella is a hybrid formed in situ with P. officinarum Vaill. as second parent species. Even though $P$. glacialis can be found all over the Alps, its origin of diffusion is likely in the western Alps. Therefore, in the western Alps, more intermediate species, generated by hybridisation of $P$. glacialis with other Pilosella species, can be found. Similarly, intermediate species are rarer in the eastern Alps, for example $P$. glaciella, which was so far unknown in Veneto.

G. Gottschlich, C. Argenti

\section{Pulmonaria officinalis L. subsp. officinalis}

+ MAR: Montefortino (Fermo), Parco Nazionale dei Monti Sibillini, Gole dell'Infernaccio (WGS84 $42.914381^{\circ} \mathrm{N} ; 13.260342^{\circ} \mathrm{E}$ ), woods along the pathway going across the gorges of Fiume Tenna, 1000 m, 24 May 2016, L. Peruzzi (FI, PI). - Species confirmed for the flora of Marche.

Pulmonaria offcinalis is a perennial species widespread in Europe, where it occurs mainly in the central part of the continent and on the mountains in the Mediterranean area (Meeus et al. 2013, Astuti et al. 2014). In Italy, it certainly occurs in moist broadleaf woods of the northern regions, including NW Toscana, and in the central Apennines (Abruzzo) (Bartolucci et al. 2012, Cecchi and Selvi 2015). On the other hand, it was historically recorded from the Marche (Paolucci 1890-1891), but its presence in this administrative region was excluded by later authors (Pignatti 1982, Conti et al. 2005, Ballelli et al. 2010, Cecchi and Selvi 2015). Our finding confirms its presence in the Marche and particularly in one of the sites where it was historically recorded, i.e., Montefortino (Paolucci 1890-1891).

L. Peruzzi \& G. Astuti

\section{Scorzonera villosa Scop. subsp. columnae (Guss.) Nyman (Asteraceae)}

+ ABR: Lentella (Chieti), pendici del M. Calvario (WGS84: $41.992746^{\circ} 14.688606^{\circ}$ ), $330 \mathrm{~m}$ s.l.m., pendii aridi, 12 April 2010, F. Bartolucci s.n. (APP, FI). - Species new for the flora of Abruzzo.

Scorzonera villosa Scop. subsp. columnae is endemic to southern Italy (Peruzzi et al. 2014, 2015). It has been recorded in Campania, Puglia, Basilicata, Calabria, and Sicilia (Conti et al. 2005). The previous record of Scorzonera hirsuta L. for Lentella in southern Abruzzo (Conti and Manzi 1996) is to be referred to this species.

F. Conti, F. Bartolucci 


\section{Silene roemeri Friv. subsp. staminea (Bertol.) Nyman (Caryophyllaceae)}

+ CAL: Castrovillari (Cosenza), Monte Pollino, loc. Canale Malavento (WGS84: $39.899424^{\circ} \mathrm{N} ; 16.200165^{\circ} \mathrm{E}$ ), prati calcarei, $1980 \mathrm{~m}, 1$ July 2015, Leg. D. Puntillo, Det. D. Puntillo \& C. Gangale (FI, CLU). - Subspecies new for the flora of Calabria.

Silene roemeri subsp. staminea is endemic to the central and southern Apennines (Peruzzi et al. 2014, 2015). Revaluated by Foggi and Ricceri (1993), it was successively recognized at subspecies level (Greuter 1995), as a vicariant of the Balkan S. roemeri subp. roemeri. In Foggi and Ricceri (1993), a record for Mt. Pollino is reported: "Calabria - Appennino Calabro-Lucano. Gruppo del Pollino, Serra delle Ciavole, praterie cacuminali esp. Ovest, alt. 2100, 25.7.1972, Nardi, Bavazzano, Posca, as S. roemeri Friv. (FI)". Accordingly, Conti et al. (2005) indicated this taxon for Basilicata. A small population was recently observed in the upper grasslands between the peaks of Mt. Pollino and Serra Dolcedorme, close to the regional border, on the Calabrian side, confirming its presence in both administrative regions.

D. Puntillo, C. Gangale

Trifolium hirtum All. (Fabaceae)

+ UMB: Castel Giorgio (Terni), all'ingresso del paese (WGS84: $42.703224^{\circ} \mathrm{N}$; $\left.11.982842^{\circ} \mathrm{E}\right)$, scarpata rupestre con prato arido, $544 \mathrm{~m}, 25$ June 2016, A. Scoppola (FI, UTV n. 34152). - Species new for the flora of Umbria.

This submediterranean annual species, partially spread in the Italian peninsula (Lombardia, Veneto, Toscana, Lazio and Calabria, Conti et al. 2005), grows mostly in dry hillsides, arid grasslands and roadsides, on acidic or acidified dry and poor soils. Trifolium hirtum was described by Carlo Allioni from Piemonte, "Loc. in Monteferrato secus agros" (Allioni 1798), and the original material is in TO. The presence in Piemonte is nowadays in doubt; moreover, it is not confirmed in Liguria (Conti et al. 2005). Considering that the Italian distribution range for this species shows many gaps (Conti et al. 2005), a larger occurrence and regional confirmations are to be expected through further investigation.

A. Scoppola

Vicia narbonensis L. subsp. serratifolia (Jacq.) Ces. (Fabaceae)

+ CAL: Morano Calabro (Cosenza), lungo la strada per Piano di Ruggio (WGS84: $39.900524^{\circ} \mathrm{N} ; 16.098626^{\circ} \mathrm{E}$ ), margine di faggeta, altitudine $1521 \mathrm{~m}, 8$ June 2016 , Leg. D. Puntillo, Det. D. Puntillo \& C. Gangale (FI, CLU, Herb. Gangale \& Uzunov). - Subspecies confirmed for the flora of Calabria. 
Less widespread than the nominal subspecies, $V$. narbonensis subsp. serratifolia is easily recognizable for the number of teeth on leaves, stipules, and the number of flowers. Old records for Calabria at Mt. Sila by Sarfatti $(1959,1965)$ as V. narbonensis v. serratifolia were not listed in Conti et al. (2005). Terracciano (1900) also refers $V$. serratifolia Jacq. from Mt. Pollino (Campotenese, San Basile).

D. Puntillo, C. Gangale

\section{Viola pumila Chaix (Violaceae)}

+ LOM: Formigosa (Mantova), loc. Vecchia Fornace (WGS84: $45.117322^{\circ} \mathrm{N}$; $\left.10.858805^{\circ} \mathrm{E}\right), 21 \mathrm{~m}$ a.s.l., 16 April 2016, F. Buldrini, C. Santini (FI). - Species new for the flora of Lombardia.

Viola pumila is extremely rare at the Italian (Pignatti 1982) and European level (Schnittler and Günther 1998). This is the fifth population today known in Italy. Here $V$. pumila grows on the edge of the escarpment of a quarry basin. It is the most abundant population of Italy: the individuals are nearly 100, 62 of them were flowering and many of the remnant were young. The site is trampled and frequented by fishermen, with risk of ground slips and plant removal. The associated flora consists of very common or alien species. The discovery of this new population does not modify the risk category of $V$. pumila, which is critically endangered (Buldrini and Dallai 2011), and poses the problem of its real distribution on the national territory: the global Italian population might be partly underestimated, due to the species' scarce visibility and its presence in places considered not particularly interesting, such as semi-natural embankment meadows and the edges of small country ditches. In Italy, $V$. pumila lives at the SW margin of its distribution: the current range may be a relict of a former presence extended throughout the entire Po valley and the Venetian plain (Buldrini et al. 2013).

F. Buldrini, C. Santini

\section{References}

Aeschimann D, Lauber K, Moser DM, Theurillat J-P (2004) Flora Alpina, Vols. 1-2. Zanichelli, Bologna.

Acta Plantarum (2008) Heteropogon contortus (L.) P.Beauv. http://www.actaplantarum.org/floraitaliae/viewtopic.php? $\mathrm{t}=8138$ [accessed 22.07.2016]

Alfonso G, Frassanito A, Beccarisi L, Belmonte G (2014) Relazione Finale del Progetto: Stagni temporanei del Parco Nazionale dell'Alta Murgia: peculiarità biologiche. Report 2014. Di.S.Te.B.A., Università del Salento - Ente Parco Nazionale dell'Alta Murgia.

Allioni C (1789) Auctarium Floram Pedemontanam cum notis et emendationibus: 20. Augustae Taurinorum. 
Astuti G, Cristofolini G, Peruzzi L, Pupillo P (2014) A new subspecies of Pulmonaria officinalis (Boraginaceae) from the southern Alps. Phytotaxa 186(3): 148-157. doi: 10.11646/ phytotaxa.186.3.3

Ballelli S, Cesaretti S, Gatti R, Montenegro BF, Vitanzi A, Catorci A (2010) Catalogo bibliografico della flora vascolare dei Monti Sibillini (Appennino centrale, Italia). BraunBlanquetia 47: 1-127.

Barina Z, Pifkó D (2008) Additions and amendments to the flora of Albania. Willdenowia 38: 455-464. doi: 10.3372/wi.38.38206

Bartolucci F (2007) Notula: 1354. In: Conti F, Nepi C, Peruzzi, Scoppola A (Eds) Notulae alla checklist della flora vascolare italiana: 4 (1311-1419). Informatore Botanico Italiano 39(2): 416.

Bartolucci F, Ranalli N, Bouvet D, Cancellieri L, Fortini P, Gestri G, Di Pietro R, Lattanzi E, Lavezzo P, Longo D, Marsili S, Peccenini S, Peruzzi L, Salerno G, Soldano A, Tilia A, Turcato C, Viciani D, Wagensommer RP, Conti F (2012) Contributo alla conoscenza floristica del settore settentrionale del Gran Sasso d'Italia (Parco Nazionale del Gran Sasso e Monti della Laga) (Abruzzo): resoconto dell'escursione del Gruppo di Floristica (S.B.I.) nel 2010. Informatore Botanico Italiano 44: 355-385.

Béguinot A (1904) Materiali per una monografia del genere Myosotis L. Annali di Botanica 1: $275-295$.

Bernardo L (2014) Notula: 2028. In: Nepi C, Peccenini S, Peruzzi L (Eds) Notulae alla checklist della flora vascolare italiana: 17 (2027-2070). Informatore Botanico Italiano 46(1): 71.

Bertolli A, Prosser F (2011) Segnalazioni Floristiche Tridentine, VIII. Annali dei Musei CiviciRovereto 26 (2010): 269-318.

Bertoloni A (1838) Flora Italica, Vol. 3. Richardi Masii, Bologna.

Biscotti N (2002) Botanica del Gargano, Vols. 1-2. Gerni Ed., San Severo.

Bolzon P (1920) Flora della Provincia di Parma e del confinante Appennino Tosco-LigurePiacentino. Tip. Ricci, Savona.

Bovio M (2014) Flora vascolare della Valle d'Aosta. Repertorio commentato e stato delle conoscenze. Testolin Ed., Sarre (Aosta).

Buldrini F, Dallai D (2011) Schede per una Lista Rossa della Flora vascolare e crittogamica italiana: Viola pumila Chaix. Informatore Botanico Italiano 43(2): 435-438.

Buldrini F, Conte L, Dallai D, Ferrari C (2013) Genetic diversity of the rare and endangered meadow violet (Viola pumila Chaix) at the southern margin of its range. Plant Biosystems 147(3): 563-572. doi: 10.1080/11263504.2012.754383

Carta A, Pierini B, Alessandrini A, Frignani F, Peruzzi L (2010) Contributo alla conoscenza della flora vascolare endemica di Toscana ed aree contermini. 1. Crocus etruscus Parl. (Iridaceae). Informatore Botanico Italiano 42(1): 47-52.

Caruel T (1889) Flora italiana, Vol. VIII. Le Monnier, Firenze.

Cecchi L, Coppi A, Hilger HH, Selvi F (2014) Non-monophyly of Buglossoides (Boraginaceae: Lithospermeae): phylogenetic and morphological evidence for the expansion of Glandora and reappraisal of Aegonychon. Taxon 63(5): 1065-1078. doi: 10.12705/635.4

Cecchi L, Selvi F (2015) Synopsis of Boraginaceae subfam. Boraginoideae tribe Boragineae in Italy. Plant Biosystems 149(4): 630-677. doi: 10.1080/11263504.2015.1057261 
Clayton WD (1980) Heteropogon Pers. In: Tutin TG, Heywood VH, Burges NA, Moore DM, Valentine DH, Walters SM, Webb DA (Eds) Flora Europaea, Vol. 5. Cambridge University Press, Cambridge, 266.

Conti F, Abbate G, Alessandrini A, Blasi C (Eds) (2005) An annotated checklist of the Italian vascular flora. Palombi Editori, Roma.

Conti F, Alessandrini A, Bacchetta G, Banfi E, Barberis G, Bartolucci F, Bernardo L, Bonacquisti S, Bouvet D, Bovio M, Brusa G, Del Guacchio E, Foggi B, Frattini S, Galasso G, Gallo L, Gangale C, Gottschlich G, Grünanger P, Gubellini L, Iiriti G, Lucarini D, Marchetti D, Moraldo B, Peruzzi L, Poldini L, Prosser F, Raffaelli M, Santangelo A, Scassellati E, Scortegagna S, Selvi F, Soldano A, Tinti D, Ubaldi D, Uzunov D, Vidali M (2007) Integrazioni alla checklist della flora vascolare italiana. Natura Vicentina 10(2006): 5-74.

Conti F, Bartolucci F (2016) The vascular flora of Gran Sasso and Monti della Laga National Park (Central Italy). Phytotaxa 256(1): 1-119. doi: 10.11646/phytotaxa.256.1.1

Conti F, Bartolucci F, Manzi A, Paolucci M, Santucci B, Petriccione B, Ciaschetti G, Stinca A (2016) Integrazioni alla flora vascolare dell'Italia centrale. Atti Società Toscana di Scienze naturali, Memorie, serie B 122 (2015): 33-42.

Conti F, Manzi A (1996) Note floristiche per Abruzzo, Molise e Puglia. Archivio Geobotanico 2(1): 83-90.

D’Amico FS, Signorile G (2001) Osservazioni sulle comunità vegetali igrofile nei "laghi" di Conversano (Ba). In: Macchia F (Ed.) Territorio e Società nelle aree meridionali - Atti del convegno, Bari-Matera, 24-27 Ottobre 1996. Mario Adda Editore, Bari, 137-146.

D’Amico FS, Signorile G, Forte L (2003) Aspetti botanici ed ecologici del "laghi di Conversano (Ba). In: Montacchini F, Soldano A (Eds) Atti del Convegno Nazionale "Botanica delle zone umide". Vercelli - Albano Vercellese 10-11 Novembre 2000. Atti Mus. Reg. Sci. Nat. Torino. Ages Arti Grafiche S.p.a., Torino, 231-248.

Danin A (2000) The Nomenclature News of Flora Palaestina. Fl. Medit. 10: 109-172.

De Martis G, Serri G, Mulas B (2009) Notula 1620. In: Nepi C, Peccenini S, Peruzzi L (Eds) Notulae alla checklist della flora vascolare italiana: 8 (1568-1622). Informatore Botanico Italiano 41(2): 358.

De Notaris G (1844) Repertorium florae ligusticae. Ex Regio Typographeo, Taurini, 495 pp. Euro+Med (2006 onwards) Euro+Med PlantBase - the information resource for Euro-Mediterranean plant diversity. Published on the Internet http://ww2.bgbm.org/EuroPlusMed/ [accessed 22.07.2016]

Fenaroli L (1970) Florae Garganicae Prodromus. Pars Altera. Webbia 24(2): 435-578. doi: 10.1080/00837792.1970.10669916

Fernandes RB (1972) Buglossoides Moench. In: Tutin TG, Heywood VH, Burges NA, Moore DM, Valentine DH, Walters SM, Webb DA (Eds) Flora Europaea, Vol. 3. Cambridge University Press, Cambridge, 87-88.

Fiori A (1907) Flora Analitica d'Italia, Vol. 4(1). Tipografia del Seminario, Padova.

Fiori A (1925) Nuova flora analitica d'Italia, Vol. II(1). Tipografia M. Ricci, Firenze, 1-160.

Foggi B, Ricceri C (1993) On the revaluation of Silene staminea Bertol. (Caryophyllaceae) Webbia 47(2): 191-201. doi: 10.1080/00837792.1993.10670540 
Gavioli O (1932) Contributo allo studio della Flora Del M. Pollino. Archivio botanico per la sistematica, fitogeografia e genetica (storica e sperimentale) VIII: 46-64.

Giannico S (Ed.) (2011) Territorio e ambiente dell'Arco Jonico. Elementi per un programma di valorizzazione. Amministrazione Provinciale di Taranto - Università degli Studi di Bari, Dpt. di Economia e Politica Agraria, Estimo e Pianificazione Rurale, Adda Editore, Bari.

Grau J (1968) Cytotaxonomische bearbeitung der gattung Myosotis L. III. Die annuellen sippen. Mitteilungen der Botanischen Staatssammlung München 7: 17-100.

Greuter W, Burdet HM, Long G (1986) Med-Checklist, Vol. 3. Dycotiledones (Convolvulaceae-Labiatae). Conservatoire et Jardin botaniques de la Ville de Genève, Genève.

Greuter W, Burdet HM, Long G (1989) Med-Checklist, Vol. 4. Dycotiledones (LauraceaeRhamnaceae). Conservatoire et Jardin botaniques de la Ville de Genève, Genève.

Greuter W (1995) Studies in Greek Caryophylloideae: Agrostemma, Silene, and Vaccaria. Willdenowia 25: 105-142.

Harpke D, Carta A, Tomović G, Ranđelović V, Ranđelović N, Blattner FR, Peruzzi L (2015) Phylogeny, karyotype evolution and taxonomy of Crocus ser. Verni (Iridaceae). Plant Systematics and Evolution 301(1): 309-325. doi: 10.1007/s00606-014-1074-0

Harpke D, Peruzzi L, Kerndorff H, Karamplianis T, Constantinidis T, Ranđelović V, Ranđelović N, Juković M, Pasche E, Blattner FR (2014) Phylogeny, geographic distribution, and new taxonomic circumscription of the Crocus reticulatus species group (Iridaceae). Turkish Journal of Botany 38: 1182-1198. doi: 10.3906/bot-1405-60

Hörandl E, Raab-Straube E von (2015) Ranunculeae. In: Euro+Med Plantbase - the information resource for Euro-Mediterr anean plant diversity. http://ww2.bgbm.org/EuroPlusMed/PTaxonDetail.asp?NameCache=Ficaria+calthifolia\&PTRefFk=7500000 [accessed 28.10.2016]

Klimko M, Truchan M, Wysakowska I (2013) Fruit and seed morphology of the genus Heracleum L.(Apiaceae) in Poland. Roczniki Akademii Rolniczej w Poznaniu. Botanika-Steciana 17: 13-24.

Licht W, Wagensommer RP (2008) Nuove acquisizioni per la flora della Puglia. Informatore Botanico Italiano 40(1): 15-22.

Meeus S, Honnay O, Jacquemyn H (2013) Differences in fine-scale spatial genetic structure across the distribution range of the distylous forest herb Pulmonaria officinalis (Boraginaceae). BMC Genetics 2013 14: 101. doi: 10.1186/1471-2156-14-101

Nazzaro R, Menale B, La Valva V (2007) Check-list della flora del Monte Taburno (Campania). Delpinoa 47 (2005): 37-55.

Nikolić T (Ed.) (2016) Flora Croatica Database. Department of Botany, Faculty of Science, University of Zagreb. Published on the Internet http://hirc.botanic.hr/fcd [accessed 3.11.2016] Paolucci L (1890-91) Flora Marchigiana. Tipografia Federici, Pesaro.

Parlatore F (1858) Flora Italiana, Vol. 3. Le Monnier, Firenze.

Perazza G (2016) Epipogium aphyllum Sw. In: GIROS (Eds) Orchidee d'Italia. Guida alle orchidee spontanee. Il Castello, Cornaredo, Milano, 318.

Peruzzi L (2016a) Crocus heuffelianus (Iridaceae), a new record for the Italian flora. Phytotaxa 261(3): 291-294. doi: 10.11646/phytotaxa.261.3.10

Peruzzi L (2016b) (768) Proposal to reject the name Crocus purpureus (Iridaceae). Taxon 65(4): 886. doi: $10.12705 / 654.21$ 
Peruzzi L, Carta A (2011) Crocus ilvensis sp. nov. (sect. Crocus, Iridaceae), endemic to Elba Island (Tuscan Archipelago, Italy). Nordic Journal of Botany 29(1): 6-13. doi: 10.1111/j.17561051.2010.01023.x

Peruzzi L, Conti F, Bartolucci F (2014) An inventory of vascular plants endemic to Italy. Phytotaxa 168(1): 1-75. doi: 10.11646/phytotaxa.168.1.1

Peruzzi L, Ganz C, Bovio M (2013) Notulae: 2000-2001. In: Barberis G, Nepi C, Peccenini S, Peruzzi L (Eds.) Notulae alla Checklist della flora italiana: 16. Informatore Botanico Italiano 45(2): 299-300.

Peruzzi L, Domina G, Bartolucci F, Galasso G, Peccenini S, Raimondo FM, Albano A, Alessandrini A, Banfi E, Barberis G, Bernardo L, Bovio M, Brullo S, Brundu G, Brunu A, Camarda I, Carta L, Conti F, Croce A, Iamonico D, Iberite M, Iiriti G, Longo D, Marsili S, Medagli P, Pistarino A, Salmeri C, Santangelo A, Scassellati E, Selvi F, Soldano A, Stinca A, Villani M, Wagensommer RP, Passalacqua NG (2015) An inventory of the names of vascular plants endemic to Italy, their loci classici and types. Phytotaxa 196(1): 1-217. doi: 10.11646/phytotaxa.196.1.1

Pignatti S (1982) Flora d'Italia, Vols. 1-3. Edagricole, Bologna.

Raffaelli M (1982) Contributi alla conoscenza del genere Polygonum L. 4. Le specie italiane della sect. Polygonum. Webbia 35(2): 361-406. doi: 10.1080/00837792.1982.10670232

Raimondo FM, Domina G, Spadaro V (2010) Checklist of the vascular flora of Sicily. Quaderni di Botanica ambientale e applicata 21(2010): 189-252.

Ricca L (1870) Catalogo delle piante vascolari spontanee della zona olearia nelle due Valli di Diano Marina e di Cervo. Atti della Società Italiana di Scienze Naturali 13: 60-143.

Rich TCG, Nicholls-Vuille FL (2001) Taxonomy and distribution of European Damasonium (Alismataceae). Edinburgh Journal of Botany 58(1): 45-55. doi: 10.1017/s0960428601000464

Roskov Y, Abucay L, Orrell T, Nicolson D, Flann C, Bailly N, Kirk P, Bourgoin T, DeWalt RE, Decock W, De Wever A (Eds) (2016) Species 2000 \& ITIS Catalogue of Life, 2016 Annual Checklist. Species 2000: Naturalis, Leiden, the Netherlands. ISSN 2405-884X. Digital resource at www.catalogueoflife.org/annual-checklist/2016 [accessed 27.10.2016]. Sarfatti G (1959) Prodromo della flora della Sila (Calabria). Webbia 15(1): 169-248. doi: 10.1080/00837792.1959.10669697

Sarfatti G (1965) Prodromo della flora della Sila (Calabria), parte II. Webbia 20(2): 355-425. doi: 10.1080/00837792.1965.10669820

Schnittler M, Günther KF (1999) Central European vascular plants requiring priority conservation measures - an analysis from national Red Lists and distribution maps. Biodiversity and Conservation 8: 891-925.

Sell PD (1994) Ranunculus ficaria L. sensu lato. Watsonia 20(1): 41-50.

Strid A, Tan K (1999) Myosotis speluncicola (Boiss.) Rouy. In: Greuter W, Raus T (Eds) MedChecklist Notulae 18. Willdenowia 29: 51-67. doi: 10.1023/A:1008828704456

Talavera S, Talavera MM (2010) Damasonium Mill. In: Talavera S, Gallego MJ, Romero Zarco C, Herrero A (Eds) Flora iberica. Vol. XVII - Butomaceae-Juncaceae, 18-22.

Terracciano N (1900) Addenda ad Synopsidem plantarum vascularium Montis Pollini. Annuario del R. Istituito Botanico di Roma, Vol. IX: 23-88.

Tison J-M, De Foucault B (2014) Flora Gallica - Flore de France. Biotopes, Mèze. 
Tutin TG (1968) Heptaptera Margot \& Reuter. In: Tutin TG, Heywood VH, Burges NA, Moore DM, Valentine DH, Walters SM, Webb DA (Eds) Flora Europaea, Vol. 2. Cambridge University Press, Cambridge, 344.

USDA (2011) USDA, ARS, National Genetic Resources Program. Germplasm Resources Information Network - (GRIN) [Online Database]. National Germplasm Resources Laboratory, Beltsville, Maryland. https://npgsweb.ars-grin.gov/gringlobal/taxonomydetail.aspx?id=18953 [accessed 19.07.2016]

Veldkamp JF (2015) De nomenclatuur van Speenkruiden (Ficaria verna Huds. s.l., Ranunculaceae). Gorteria 37(3-4): 84-116.

Vignolo-Lutati F (1953) Hieracia Pedemontana. Catalogo sistematico. Allionia 1(2): 289-456.

Vuille FL (1987) Reproductive biology of the genus Damasonium (Alismataceae). Plant Systematics and Evolution 157: 63-71. doi: 10.1007/BF00939181

Wagensommer RP, Marrese M, Perrino EV, Bartolucci F, Cancellieri L, Carruggio F, Conti F, Di Pietro R, Fortini P, Galasso G, Lattanzi E, Lavezzo P, Longo D, Peccenini S, Rosati L, Russo G, Salerno G, Scoppola A, Soldano A, Stinca A, Tilia A, Turco A, Medagli P, Forte L (2014) Contributo alla conoscenza floristica della Puglia: resoconto dell'escursione del Gruppo di Floristica (S.B.I.) nel 2011 nel settore meridionale dei Monti della Daunia. Informatore Botanico Italiano 46(2): 175-208.

Wagensommer RP, Medagli P, Perrino EV (2013) Piante vascolari minacciate e Liste Rosse: aggiornamento delle conoscenze in Puglia. Informatore Botanico Italiano 45(2): 393-432.

Zahn KH (1922-1938) Hieracium. In: Ascherson PFA \& Graebner KOPP: Synopsis der mitteleuropäischen Flora 12(1): 1-80 (1922), 81-160 (1924), 161-400 (1929), 401-492 (1930); 12(2): 1-160 (1930), 161-480 (1931), 481-640 (1934), 641-790 (1935); 12(3): 1-320 (1936), 321-480 (1937), 481-708 (1938). Borntraeger, Leipzig, Berlin. 